Culture Moves?

\title{
The Festival of Pacific Arts and Dance Remix in
}

\author{
Oceania
}

\author{
Katerina Martina Teaiwa \\ Australian National University
}

\begin{abstract}
This reflective essay is a journey through my dance studies work with a discussion on the role of the Festival of Pacific Arts in shaping dance in Oceania, and particularly its impact on Banaban dance from Rabi in Fiji. I encourage future discussion and development of a field of 'Pacific Dance Studies,' with preliminary thoughts on the role of 'remix' in Pacific dance practices, especially as they are shaped by and reflected in this important regional festival.
\end{abstract}

\section{PRELUDE}

On a rainy day in July 2012 in the middle of the two-week long Festival of Pacific Arts, I flagged down a taxi and asked the driver to make haste to what I thought was the venue of the Kiribati Independence Day celebrations in Honiara. I arrived at the drenched stadium to find several dancers from the Rabi High School performance group waiting for a bus to take them to the Pacific Casino Hotel where the festivities had been relocated. The bus came and we made off with the teenagers laughing and bantering with their Solomon Islander liaison officer. We arrived at the venue and it suddenly struck me that I would be viewing three different versions of I-Kiribati culture under one roof, representing three different corners of the Kiribati diaspora-the Solomon Islands where over two thousand Gilbert Islanders were resettled in the 1950s and 60s, the Fiji Islands where over a thousand Banabans and Gilbertese had been moved as a result of phosphate mining and World War II, and I-Kiribati from Kiribati, the home country now facing the perceived, imminent threat of sea level rise.

Mary Elizabeth Lawson (1989) had described Kiribati dance in her research as bai n abara, or 'a thing of our land', but it struck me that 'the land' in question was not necessarily where these communities currently lived. Or was it? As each 
group performed, it was clear that the choreographies were based on a shared movement vocabulary, particularly reflecting the flight and movement of frigate birds, but each had added other movement styles and gestures so they were both connected and distinct. This was reinforced by the fact that while all the singing was in the Kiribati (Gilbertese) language, each set of costumes also reflected different versions of a shared design. Both the dances and costumes were a remix of recognizable forms. These observations in the middle of this major regional festival that serves as the bastion for the expression of 'traditional' Pacific arts reinforced my long-held belief that the often perceived boundaries between ritual, traditional or community dance, and contemporary, modern or popular dance can be unproductive and unreflective of the complexity and dynamism of history and of choreographic expressions of culture across Oceania.

\section{INTRODUCTION}

In this essay I reflect on the role of the Festival of Pacific Arts in shaping dance in Oceania. In 1972, the quadrennial Festival of Pacific Arts (FOPA) was established by the South Pacific Commission to promote, develop and safeguard indigenous expressions of culture in Oceania. Forty years and eleven festivals later, the event is still going strong with thousands of local and visiting participants and artists sharing a wide range of cultural practices, including dance, music, painting, carving, tattooing, filmmaking, architecture, healing arts, ceremonial arts, navigation and canoeing, culinary arts, fashion design, literature and much more. Each festival attracts more than two thousand artists from around twenty-seven countries or territories and since 1996 has rotated between a Polynesian, Melanesian and Micronesian host country.

What is particularly unique about FOPA is that it is conceived, hosted and presented by Pacific people for a Pacific audience, rather than primarily framed by tourism. The economic gain expected by hosts is additional to the main goal of demonstrating the cultural vitality of participating contingents and the societies they represent. FOPA illustrates the agency and will of each country to mobilise economic, political and cultural resources to support participation and the capacity

of the host country to successfully mount and manage the dynamic and complex two-week event. The gathering signals and relies upon a wide range of factors including cultural resilience, intra-Pacific kinship, artistic exchange and creative competition, as well as Pacific national and regional cultural diplomacy, economics and politics. 
I will discuss the performing arts element of the festival in catalysing and transforming dance practices as well as reflect on the expansion of genres to include diasporic and other contemporary expressions, with a particular look at Banaban dance. I use the concept of 'remix' to reflect on the agency, politics and creativity embedded in Pacific dance in the context of pre-colonial and colonial histories of exchange and the so-called postcolonial or globalising present.

\section{MY DANCE JOURNEY}

First I would like to offer a bit of context for my own dance experiences, interests and work. In 2002 after a year of fieldwork, I created a video montage which tracked a contemporary Pacific dance to the popular Tokelauan song 'Pate Pate' across several islands and cities in Oceania. Beginning in Betio, Tarawa in Kiribati with three young girls practising one version in daylight for a birthday party, it moves to another house in Tarawa with a solo dancer under an electric light, then to Tanaeang on Tabiteuea with two nuns and I performing at night, then to Rabi in Fiji with a family group lit by benzene lamps, laughing and dancing, and finally to the bright stages of Canberra and Honolulu where professional dancers invite the audience to dance along.

Technically the montage could be any one of the hundreds of dance and music videos now produced by islanders and uploaded to YouTube. But ethnographically, each site mattered and was connected in some specific way, not just by myself as a dancer and researcher, but by the frequent and rapid dissemination of Island music across the Pacific via all manner of technology, and historically through colonialism, and missionary and labour trade networks. While music moves faster than choreography, the movement vocabularies signalled in each of these sites highlighted both local or geographically specific performance styles, as well as a remix of Pan-Pacific and especially what Islanders themselves, and tourists, imagine as generic Polynesian movements (such as swaying hips and telling stories through hand gestures). This process of editing the dance footage helped me to reimagine dance practices in terms of the manner in which choreographies in the Pacific Islands often function to bear and maintain certain social values and corporeal histories while still travelling across cultural and political boundaries and producing both new and familiar styles of movement.

Globalisation and diaspora studies often focus on the movement of people, ideas and commodities, and in dance studies on popular or classical forms of dance, but less on the exchanges between indigenous, islander and what some 
might term third or fourth world communities (see for example, Rowe, 2010). In Pacific Islands Studies you are still more likely to encounter scholarship focused just on one culture, island, people or country than on the dynamics between islands, peoples, cultures and regions. This often leads to a conflation between, for example, Māori, Samoan or Tongan specific studies and methods, and regional or area 'Pacific studies' and approaches. Such approaches are described by Teresia Teaiwa (2010) as interdisciplinary, accounting for indigenous ways of knowing and comparative (not focusing on just a single ethnicity, nation or locality). This is where my experience growing up in multicultural Fiji becomes relevant.

There is a beautiful saying from Kiribati that artist and educator Teweiariki Teaero once told my students when I was teaching at the University of Hawai'i. He said: "In Kiribati, you know your parents love you if they help you to dance ... you know your parents love you, if they help you to dance" (Teaero, personal communication, 2005). Along with my two sisters, Teresia and Maria, I was raised in Fiji by an African American mother and a Banaban and I-Kiribati father to appreciate a wide range of dance practices. While there was no accredited dance studies training or education at primary, secondary or tertiary levels, dance was a key expression of the multitude of Pacific cultures that make up the population of Fiji and in Suva in particular. We were surrounded by and regularly got opportunities to learn Fijian, Rotuman, Samoan, Cook Islands, Tahitian, Tongan, Indo-Fijian, European and Chinese performance traditions and practices.

Māori artist and long-time Fiji resident Duffy Kingi occasionally taught jazz and contemporary dance and a group of expatriate women, including my mother, Joan, started the Suva Ballet School, which offered classes for several years at St Luke's and then St John the Worker's church halls. Eventually most of the dance teachers left and the school closed but from time to time a modern dance or gymnastics instructor would pass through and the YWCA would set up classes for anyone who was interested. Children also taught themselves some version of breaking, popping and locking by regularly viewing films such as Beat Street and Breakin'. School concerts and the tourism industry provided some opportunities for stage performances, but for the most part we danced in community halls, gyms and on rugby fields.

I eventually went on to university in California and then Hawai' $i$ and continued to study ballet, jazz, modern dance and hula, but every American summer and winter holidays, I returned to Fiji to dance in hotels, at fashion shows, and with personalities such as I-Kiribati chef, magazine editor and dancer Neil 
Foon. In 1997 I met the wonderful late Professor Epeli Hau'ofa at the University of the South Pacific (USP) and he introduced me to a passionate choreographer, who is now the inaugural president of the Samoan Arts Council, Tuilagi Seiuli Allan Alo. I then became a founding member with Allan of the Oceania Dance Theatre at the Oceania Centre at USP and worked on two major productions which were staged in Suva, Honolulu and Canberra, titled the Boiling Ocean I and II. Today, the Oceania Dance Theatre forms part of the well-supported and thriving Oceania Centre for Arts, Culture and Pacific Studies at USP. In the absence of a formal curriculum in dance studies, performing arts or dance education, dancers, visual artists, musicians and singers collaborate at the Oceania Centre on numerous productions now led by composer and artistic director Igelese Ete from Samoa and New Zealand, and choreographer Peter Espiritu from Hawai' $i$.

While dance has been part of my life from early childhood, I studied Science, Pacific Islands Studies and Anthropology at University and never joined an academic dance programme. Years later, I then began integrating dance into the field of interdisciplinary Pacific Studies as a PhD student and then assistant professor. Dance seemed to be one of those things ethnomusicologists sometimes engaged with alongside Pacific music, but in the early 2000s, I found that, with the exception of a few scholars such as Adrienne Kaeppler (1972), Jennifer Shennan (1981), Amy Stillman (1998), Jane Moulin (1979), Mary Elizabeth Lawson (1989), Vilsoni Hereniko (1991) and Richard Moyle (1991), there was very little research and writing on traditional Pacific dance cultures and practices and almost nothing on contemporary Pacific dance. Today there are a few more including Jane Desmond (1998), April Henderson (2006), Vilsoni Hereniko (2006), Christopher Balme (2007), Kalissa Alexeyeff (2009), Petra Autio (2010), Rosita Henry (2011), Naomi Faik Simet (2012), Ojeya Cruz (2011), Moana Nepia (2013), and Ralph Buck and Nicholas Rowe (2014), for example, some of whom work in indigenous, multimedia, dance or cultural studies, and others in anthropology, ethnomusicology or beyond academia.

In my own work I discuss and explore the potential of dance for interdisciplinary Pacific Studies, considering what dance can tell us about history, politics, culture, society, nationalism, regionalism and globalisation in Oceania (Teaiwa 2008, 2012). I investigate how both choreographed and everyday body movements reflect broader cultural, political and economic values and principles; the lack of dance education, dance studies and relevant arts policy in the Islands, and the question of how to articulate a specific field of 'Pacific Dance Studies'. 
In most Pacific islands, with the exception of settler colonies such as Hawai' $i$ and New Zealand with its strong Māori language and arts programmes, local cultures are often assumed to be strong and resilient, as regularly expressed at gatherings like FOPA, and few policy measures are taken to actually integrate indigenous languages, arts and knowledges into the classroom at any education level. Samoa, Tonga and Fiji, for example, are just beginning to value and formalise arts education. Thus my approach in exploring these issues over the last few years has been to integrate dance topics and dance histories into Pacific Studies classes, and I often require my social science students to move in and beyond their university classrooms. I undertake research on the role of dance, popular culture and the arts in shaping Pacific regionalism, and have worked on cultural and arts policy strategies with the Human Development Programme of the Secretariat of the Pacific Community (K. Teaiwa, Henderson, \& Mallon, 2012, \& K. Teaiwa, 2002, 2008, 2011, 2012). And, while teaching Pacific Studies at the University of Hawai' $i$, I convened the first international Pacific dance studies conference, Culture Moves! Dance in Oceania from Hiva to Hip Hop (University of Hawai'i, 2005), with Sean Mallon and April Henderson in 2005 in Wellington.

\section{CULTURE MOVES!}

In convening Culture Moves! our main goal was to create a diverse Pacific Dance Studies space; to get what people called "traditional" Pacific dance, contemporary dance and hip hop all into one academic and performance space, host diverse panelists and practitioners representing both the Islands and the Pacific diaspora, and reflect on the current state of dance practice, education and histories in Oceania (Hereniko, 2006). 


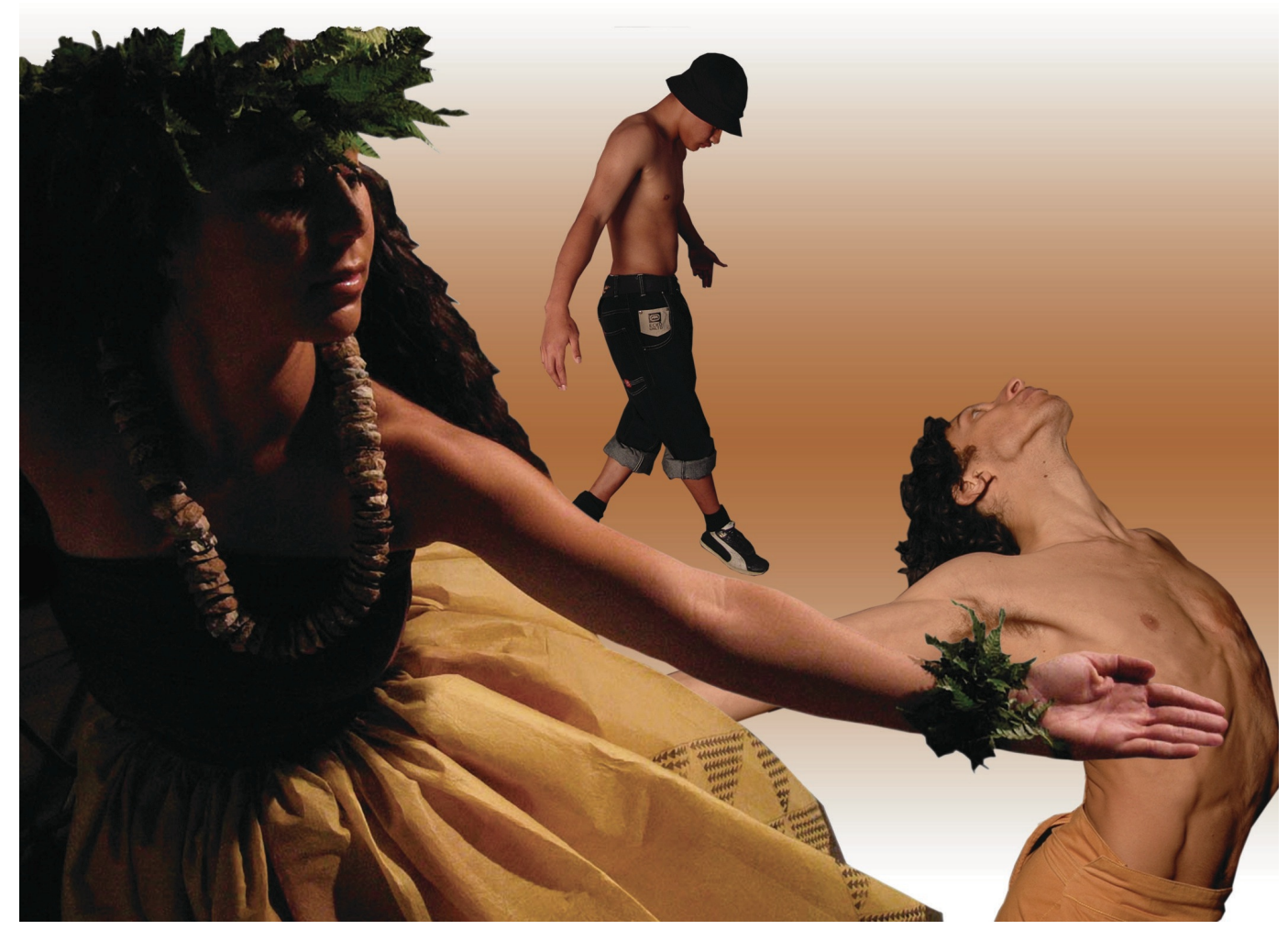

Photograph 1: Culture Moves! Conference logo (2005), design by Dean Otsuki. Contemporary dance image by J. McCauley 2004, dancer: Travis Khan, The New Zealand School of Dance; Hip hop image by DEAP @2004, dancer: B-boy 01; hula image by Michael Harada @2004, dancer: Kaohi Yojo, Mid-Pacific Institute of the Arts.

The event was held over five days at the Museum of New Zealand Te Papa Tongarewa, attracted hundreds of participants, and included speakers and panellists such as Epeli Hau'ofa, Adrienne Kaeppler, Amy Stillman, Mahealani Uchiyama, Tania Kopytko, losefa Enari, Tanemahuta Gray, Moana Nepia, Lemi Ponifasio, Victoria Holt Takamine, Julia Gray, Richard Moyle, Suga Pop, Neil leremia, Future, Louise Potiki Bryant, Charles Royal and Moss Patterson. The program was organised as panels, workshops, performances and exhibitions and included over two hundred dancers from across New Zealand and the region, and discussions of dance in historical perspective, contexts of performance, music and rhythm, choreography and movement, contemporary Māori dance, dance education and documenting the dance through labanotation.

Culture Moves! was funded and supported by Creative New Zealand, UNESCO, Te Papa, the University of Hawai' $i$, Victoria University of Wellington, and the Pacific Cooperation Foundation. One of my regrets is that aside from a website and image gallery, we were not able to put together a conference publication. There were few prepared papers, the conference was primarily oral and performance based and we ran out of funds to edit and transcribe our hours of video footage 
(but see K. Teaiwa, Henderson \& Mallon, 2012 for a related publication, and Hereniko, 2006). We had aimed for scale, publicity and thematic coverage rather than scholarly outputs and my co-conveners and I were exhausted for about a year afterwards. The event did, however, inspire other similar dance dialogues on a smaller scale which continue in New Zealand, and in 2014 Fiji hosted the inaugural Epeli Hau'ofa International Dance Festival.

After Culture Moves! I took up a position in Canberra to build an undergraduate teaching programme in Pacific Studies at the Australian National University. While the ANU does not have a dance studies programme, the current aspect of my work that engages dance and the arts involves taking Pacific Studies students into the Islands to work with arts and culture offices, projects and programmes. These are intensive undergraduate and postgraduate courses involving a practical placement or assignment in the arts, culture, heritage and education fields. Students track their professional development, and produce blogs, evaluations and reports on their assignment and a short analytical paper. We have now been to Fiji twice to work with the Fiji Arts Council, National Trust, Department of Culture and Heritage, Secretariat of the Pacific Community, and Fiji National University, and to Samoa to collaborate with Allan Alo from USP, Leua Latai from the National University of Samoa and the Samoa Arts Council. Our 2013 Samoa collaboration involved all sixteen students, regardless of major or degree (none were in the performing arts), dancing in two multimedia shows on Upolu. In 2012 eighteen of us, including undergraduates, Honours, Masters and PhD students, were privileged to participate in the Festival of Pacific Arts in Honiara, Solomon Islands.

\section{THE FESTIVAL OF PACIFIC ARTS AND BANABAN DANCE}

For most of its life, the Festival of Pacific Arts has been managed by a regional Council of Pacific Arts which is also the primary advisory body representing cultural officers and representatives of all the Secretariat of the Pacific Community's (SPC) member states and territories. A key aspect of the festival was that all delegations had to represent these nations, states and territories, making it very difficult for independent or diasporic artists, regional organisations or arts collectives and other non-state groups to participate. Diasporic groups include those who are the products of intra-Pacific resettlement or displacement. I turn now to the role of the forty-year-old festival in both sustaining and transforming dance in Oceania with a specific look at its impact on one such diasporic group, the Banabans, and 
what I am exploring as cultural remix. Banaba, also known as Ocean Island, is a raised coral atoll with extensive deposits of phosphate rock. It was incorporated into the Colony of the Gilbert and Ellice Islands in the early 1900s and is today part of the Republic of Kiribati. The Banabans were displaced to Fiji in 1945 because of this valuable phosphate rock which was mined by a company owned conjointly by Britain, Australia and New Zealand (see K. Teaiwa, 2000, 2004, 2005, 2012 \& Kempf \& Hermann, 2005).

A key figure on the Pacific arts landscape was the festival's first artistic director, the late Beth Dean, also known as Beth Carell, described by dance writer Jennifer Shennan in Dean's obituary as a performer, choreographer, critic, researcher and author. She was committed, along with her husband Victor Carell, "in the belief that Pacific performance should not be modeled solely for the tourist industry, nor be an imitation of European models" (Shennan, 2012). Dean, a ballerina, had a particular impact on the revitalization of dance on my father's island of Rabi in Fiji, the current home of the Banaban people.

Growing up as a child in Fiji, I was accustomed to both watching and performing Banaban dance outfitted in a combination of raffia, crepe paper, multicoloured foil, ribbon and, at times, shiny skirts made of VHS or Betamax videotape. Beth Dean's influence on the national contingents of the festival was to direct them to revive and perform their most ancient and treasured dances, attired in "authentic" costumes sourced from natural materials. While Pacific Islanders had been innovatively weaving in introduced colours and fabrics, and making practical use of everyday and easily accessible resources, the establishment of what was then called the South Pacific Festival of Arts in 1972, explicitly emphasised the promotion and protection of tangible and intangible heritage, and dance movement and costuming were no exception.

This was a timely coincidence for the Banabans, who were keen to show the world that they had a unique culture that was different from the rest of the Gilbert Islands and thus form the basis for a petition for separation from the Colony and sovereignty over mining revenue. The 1972 Festival of Arts inspired much community consultation, archival research and discussion. When it opened in Suva the Banabans had revived the ancient karanga dance, reconstructed their costumes using natural fibres and materials, composed new songs, and choreographed new dances to present to the rest of the region. Dance, as in most Pacific cultures, was viewed as one of, if not the, most significant expression of cultural identity. 
The performers were also recast as warriors for another urgent cause to sue the British government for the phosphate mining and destruction of their home island, 1600 miles away from their new home in Fiji. Their land had been literally dug up, dried, crushed and shipped off to fertiliser plants in Australia and New Zealand where it took on new life as superphosphate fertiliser, described by the New Zealand fertilizer journal as the "lifeblood of New Zealand farming" (1956).

A Banaban dancer, Kaiao Borerei, who attended the 1976 Festival of Arts held in Rotorua, reflected on her visit thus:

While on a bus trip through the ... countryside, we saw an aerial topdressing plane putting fertiliser onto a farm. The bus driver told us it was superphosphate from Ocean Island and that made us feel sad and stirred our hearts. It seems that some of Banaba is in New Zealand. (Shennan \& Tekenimatang, 2005, p. 116)

The festival gave Banabans a platform to revive an ancient dance, to create a new dance theatre enacting precolonial, colonial and missionary histories, the loss of land and displacement to Fiji, and also, in Beth Dean's words, create "their own [dance] style out of many ingredients" (Shennan \& Tekenimatang, 2005, p. 242). The kainikamaen or master composer, Tawaka Tekenimatang, created divinely inspired music and rhythms, and a group of women, including Makin Corrie Tekenimatang, devised the movement (Kempf, 2003). They choreographed a new Banaban style from wide-ranging Pacific, European and popular cultural sources, as well as Fijian, Tahitian, Cook Islands, Tuvaluan and Samoan dance, and various forms of Asian martial arts. These were all woven together with an I-Kiribati movement vocabulary base. Alongside the karanga, they presented this remix as 'Banaban dance' at the 1972 festival in Suva (and soon after at the opening of the Sydney Opera House), in 1976 in Rotorua, 1985 in Tahiti, and 1988 in Townsville.

After the first military coup in Fiji in 1987 that ousted a multicultural Labour government, all non-indigenous Fijian performers and items were dropped from the festival delegation and Banaban participation stopped until twenty-four years later in 2012 when the Fiji Permanent Secretary for Education happened to witness a Rabi High School students performance. The Festival of Pacific Arts was just a few weeks away when he decided to include the Rabi dancers in the Fiji national contingent. The students hurriedly applied for and were issued passports and in July that year I saw them dance in Honiara, significantly alongside contingents from Kiribati and the I-Kiribati diaspora now resident in the Solomon Islands. 
Having witnessed Banaban dance for over thirty years, I was surprised at what I saw. This was a bit different from the type of dancing Banabans had put on stage decades earlier. Both were remixes of diverse influences but the form created in the early 1970s had sedimented somewhat and was now widely recognizable as an integrated style in its own right. The 2012 dances by the Rabi students involved recorded music, which potentially reduced the power of the performance from a Banaban and I-Kiribati perspective, but most importantly, the choreography was completely created by the students themselves and not the result of a collaboration between a master composer and adult choreographers. The influences of Brittany Spears, Beyonce and everything from the twist to the Macarena, "single ladies dance" and street funk were evident. This isn't that surprising in the contemporary Pacific but it was at the Festival of Pacific Arts, which, since its inception, has rarely promoted popular or commercial dance unless strongly put forward by the national delegations themselves. New Zealand, for example, regularly features troupes such as the Māori contemporary Atamira Dance Company but to my knowledge has not ever included a hip hop crew.

There are certain expectations and understandings of what culture is at the festival and this has meant that while the gathering does give national delegations opportunities to prepare and display the best of their performing arts cultures, what counts as national dance has been somewhat restricted for forty years. Of particular concern to Pacific Islanders has been the nation-state focus of participation and representation where delegates are assumed to be indigenous to a country rather than part of a Pacific diaspora. The participation in 2008 in American Samoa of a delegation representing American Samoans from San Diego on the US continent underscored this tension. Furthermore, in 2012, Fiji included the very diverse VOU Dance Company which performs contemporary Fijian, Indo-Fijian and popular dance styles.

The Solomon Islands and festival organising committee were incredible hosts, providing all 2000 delegates with free mobile phones with $\$ 10$ worth of credit, transport, drivers and their own liaison officers for two weeks. The opening and closing celebrations were on the order of any Commonwealth or Olympics ceremonies and, most importantly, attended by tens of thousands of Solomon Islanders. This was astounding for a country that had itself experienced a coup and political turmoil for years and was described by Australian political experts as a 'failed state'. The festival provided an opportunity for Solomon Islanders to remind themselves of their resilience, efficacy and capacity for not just bringing together 
their own diverse cultures but also generously hosting delegates from over twenty countries and hundreds of additional visitors.

\section{INDIGENOUS REMIX AT FOPA}

My current work on FOPA is part of a five-year project titled "Indigenous Peoples and the Global Remix" (Pennington, 2013). The project is funded and supported by a Mellon Foundation programme called Framing the Global, a collaboration between the Centre for the Study of Global Change at Indiana University and Indiana University Press. The research builds on work conducted at the 2004 festival in Koror, Palau and the 2008 Festival in Pago Pago, American Samoa. In 2012, with the support of the ANU, the Secretariat of the Pacific Community and the Solomon Islands Festival Organizing Committee, my students and I conducted research to contribute to a planned collection commemorating the 40th anniversary of the Festival. Each student, with the support of course tutor Nicola Mariner, working alone or in pairs, depending on their level and experience, interviewed artists and delegates from all but one of the participating countries. The large Rapa Nui group had just one English-speaking member and unfortunately we had no one in our team who spoke Spanish. We did, however, have several Mandarin speakers and so were able to get strong interviews from the Taiwan contingent, which has been a feature of the gathering since 2004. Taiwan also provides major funding to the festival and makes strong claims that their indigenous groups have linguistic, genetic and cultural connections to Pacific peoples and that this aspect of their national identity sets them firmly apart from mainland China.

In my project for Framing the Global, I use the concept of remix to reflect on the agency, politics and creativity embedded in Pacific dance and related arts practices, in the context of colonial histories and the globalizing present. I've encountered the idea in a variety of discussions about Caribbean and black popular culture, as discussed in the work of Dick Hebdige (1987), intellectual property, copyright and new media, as in the work of Lawrence Lessig (2008), and that of Kimberly Christen (2005) in her writing on aboriginal remix and the cultural commons. I chose remix because unlike hybridity (Bhaba, 1994), another term from postcolonial and cultural studies to which it is closely related and associated, remix for me points to an active, agentive and creative process where people can weave together old, new and emerging ideas and materials. This has particular salience for indigenous peoples, who might be viewed as representing traditional, 
emplaced or static cultures, or locked into just reflecting the colonial experience and a colonial "other."

The concept of indigenous remix is captured in Native American artist Ryan Red Corn's Wazhazhi-pod for a 2008-2009 museum exhibition at Harvard's Peabody Museum titled REMIX: Indigenous Identities in the 21st Century (Peabody Museum of Archaeology \& Ethnology, 2013), a Native take on the famous iPod images of youthful dancers in silhouette. Ryan Red Corn was highlighting the creative and innovative ways in which Native Americans weave old and new cultural influences within the context of imperial and colonial history and globalization. Erin Reilly (2010), reflecting on remix in the context of education, writes: "Remixing is building upon a work that already exists ... To develop a remix, the creator must first consider how the original source is related to a new context” (p. 143). Furthermore, while many of us know that borrowing and fusion of diverse sources in the process of making art is common practice, acknowledgement and reflection of the implications of remixing is critical in the context of indigenous arts and culture. Movement vocabularies, musical styles and rhythms, costumes and other elements of dance are seen by particular individuals and groups to constitute their communal legacies or treasures and are sensitive to their circulation or appropriation, especially with the growing awareness of the commercial potential of culture and issues of intellectual property.

Remixing, however, is already evident in Pacific music and visual traditions such as music and tatau where perceived global forms such as reggae, for example, are integrated into the soundscape of island cultural production. Tatau has become emblematic of sport and the global brands associated with it which now signify contemporary forms of Pacific masculinity. Remixing is there in most Pacific performance genres, signalling centuries of cultural exchange, trade and dialogue between islands. Furthermore, the original idea of the SPC to create and support a festival of arts in order to safeguard tangible and intangible cultural heritage now has to contend with new contexts, new media and new forms of knowledge sharing and exchange.

Over the years the Guam delegation, for example, after receiving criticism from other contingents about the lack of perceived Pacific authenticity in their Spanish-inspired performances, choreographed new Chamorro dances in 1985 for the festival in Tahiti. Their director, Frank Rabon, had trained with Hawaiian hula halau and used hula movement vocabulary as the basis for new Chamorro dances set to Chamorro chants and music. The new Chamorro dance styles have now 
become the standard representation of indigenous dance in Guam and are a regular feature of each festival. Hawaiian contingents, however, have questioned its origins and highlighted the perceived appropriation of their hula dance forms. There are also other transformations and exchanges that have occurred as a consequence of FOPA including the production of dances for timed and staged contexts, and in particular the speeding up of music and rhythm to increase the entertainment factor. The Kiribati style of dance displayed at FOPA, for example, is very different from what you would see in a mwaneaba or meeting house back in Kiribati. They would normally have a substantial choir to back up the dancers, they would start the performance slow, and finish loud and fast, whereas at every FOPA, the travel budget requires the dancers to sing themselves and usually start and finish up-tempo.

What is also remixed for me in the festival are old and new kinships which mark a unique feature of the Pacific region. Archaeologists, linguists and anthropologists have long argued that while the region is culturally diverse, all Pacific cultures, with the exception of the much older Papuan cultures, are related with origins in South East Asia and Island and coastal Melanesia. Archaeologist Matthew Spriggs, writing of the period of Lapita expansion across the Pacific, contends that in ancient Oceania you might have met the same man or woman one year in Tonga, and the next on New Britain in PNG or in Vanuatu. Thus, three thousand years ago people from the New Guinea Islands and out as far as Tonga, Fiji and Samoa were more interconnected than at any time until the age of mass transportation began some two centuries ago. The Lapita culture is the cultural heritage of almost all Pacific Islanders today, and thus provides a powerful evidence base for shared values and connections and, I would add, the exchange of ideas, forms, patterns, rhythms and choreographies (Spriggs, 2009, p. 14). Remix, I imagine, is not a new Pacific phenomenon but a continuation of the creative and practical survival skills that islanders have developed over centuries.

But new contexts bring new challenges, new relationships and new opportunities. At the 2008 FOPA in Pago Pago it was fascinating to watch the strong kinship expressed between all the islands colonized by the US: Guam, American Samoa and Hawai'i. Each of these groups was represented by a governor, complete with their own secret service detail sweltering in suits in the hot sun, while the governors themselves wore colourful Aloha shirts, shorts and at least one wore thongs or flip-flops. 
In a rather different vein, Tonga demonstrated the centuries-old relationship of political exchange and intermarriage with Samoa by gifting their FOPA hosts with an extraordinary tapa or ngatu (barkcloth) that spanned the full length of the stadium. The significance of this astounding gift was well understood by the American Samoan hosts as a display of the mana and prowess of Tongan arts, culture and heritage. It was an expression of both competition and kinship.

In Pago Pago we also saw for the first time a delegation that did not represent a nation but a diaspora, and a primarily military one at that. American Samoa is a strong source of recruitment for the US military and both male and female youth are regularly conscripted. Across Pago Pago images of Fa'a Samoa, Samoan pride and service in the armed forces are visible throughout schools. San Diego, representing the many American Samoans who now live in that city, marched alongside the Solomon Islands and insisted on both their connections to and uniqueness from the home island culture. 'San Diego's' participation in the 2008 FOPA highlighted how national and cultural boundaries and borders of all kinds might be crossed and questioned in Oceania.

The now familiar map of Oceania based on the 1832 partitioning of the region by explorer Jules Dumont D'Urville into Micronesia, meaning small islands, Polynesia, many islands, and Melanesia, black islands (because Europeans were obsessed with race and skin colour), while reflecting real categories of identity for Pacific peoples today, needs to be interrogated in light of the actual movement of people and ideas across and beyond the islands. I've started using a new map in my teaching to reflect the manner in which boundaries and borders established by European cartographers might slip and slide if Pacific ways of mapping are included, and if we consider where in the region the Pacific diaspora now resides.

\section{DANCE STUDIES AND EDUCATION IN OCEANIA}

I conclude with a reflection on what the festival means in terms of dance education, dance studies and related arts policies in Oceania. While it provides an incredible regional platform for islanders to compose, choreograph, dance and perform for each other while reinforcing both ancient and new kinships, after forty years the festival has not resulted in the integration of arts and dance studies into the education curriculum at any level in most Pacific countries.

A faithful group of FOPA scholars who are also members of the Pacific Arts Association and the Study Group on Music and Dance in Oceania, part of the International Council for Traditional Music, has regularly documented and 
inadvertently functioned as gatekeepers of scholarship associated with the festival. There are few emerging and early career dance scholars, and certainly few from the region itself, who have followed on their heels. In the meantime and much less documented, the ubiquitous island reggae has its own dance style, Bollywood dance is very popular, and young people are krumping, breaking, popping, locking and voguing from Port Vila to Port Moresby, from Koror to Tongatapu.

There is a need for further discussion on how the festival, a forty-year-old bastion of cultural tradition and arts, can effectively integrate and display the full range of Pacific dance practices (Hereniko, 2006). Furthermore, what will it take for Pacific governments to integrate arts and dance into the primary and secondary educational curricula? What are the possibilities for more opportunities for learning and exchange between the Islands and dance communities in Australia, New Zealand, Asia and the US? Would Pacific governments and institutions include the performing arts in their list of priority tertiary education scholarships? The festival was created in the first place to safeguard and promote those forms of knowledge and creativity, such as dance, that have existed as archives and living vehicles for Pacific ideas and identities for centuries. Dance should not be seen as marginal to education.

The Pacific needs an arts and cultural policy environment regionally and nationally that supports dance education and training, including the integration and valuing of community and ritual practitioners. And the development of "Pacific Dance Studies" in both the islands and the diaspora is critical to expanding the range of research and teaching in Pacific dance. From an interdisciplinary Pacific Studies context, this field would hopefully reflect the many ways in which Pacific dance expresses both ancient and contemporary movement vocabularies, identities and meanings within the context of changing political, social, and economic environments. Like the Banabans, whose home island was devastated by mining, many island nations also now face the threat of climate change and sea level rise. The dramatic transformation of Pacific physical environments will likely have a significant impact on how we dance in the future.

\section{REFERENCES}

Alexeyeff, K. (2009). Dancing from the heart: Movement, gender and sociality in the Cook Islands. Honolulu, HI: University of Hawai' $\mathrm{i}$ Press.

Autio, P. (2010). Hard custom, hard dance: Social organisation, (un)differentiation and notion of power in a Tabiteuean community (Doctoral dissertation). University of Helsinki, Finland. 
Balme, C. (2007). Pacific performances: Theatricality and cross cultural encounter in the South Seas. Basingstoke, England: Palgrave Macmillan.

Bhaba, H. (1994). The location of culture. New York, NY: Routledge.

Buck, R., \& Rowe, N. (Eds.). (2014). Moving oceans: Celebrating dance in the South Pacific. New Delhi, India: Routledge India.

Christen, K. (2005). Gone digital: Aboriginal remix and the cultural commons. International Journal of Cultural Property, 12, 315-345.

Cruz, O. (2011). Dancing te Moana: Interdisciplinarity in Oceania. Brolga, 35, 75-83.

Desmond, J. (1999). Staging Tourism: Bodies on display from Waikiki to Sea World. London: University of Chicago Press.

Hebdige, D. (1987). Cut 'n' mix: Culture, identity and Caribbean music. New York, NY: Methuen.

Henderson, A. (2006). Dancing between islands: Hip hop and Samoan diaspora. In B. Dipannita \& S. J. Lamellae (Eds.), The vinyl ain't final: Hip hop and the globalization of Black popular culture (pp.180-199). London, England: Pluto Press.

Henry, R. (2011). Dancing diplomacy: Performance and the politics of protocol in Australia. In E. Hviding \& K. Rio (Eds.), Made in oceania: Social movements, cultural heritage and the state in the Pacific (pp.179-193). Wantage, England: Sean Kingston Publishing.

Hereniko, V. (1991). Dance as a reflection of Rotuman culture. In A. Fatiaki et al. (Eds.), Rotuma: Hanue pumua [Precious land] (pp. 120-142). Suva, Fiji: Institute of Pacific Studies, University of the South Pacific.

Hereniko, V. (2006). Dancing Oceania: The Oceania Dance Theatre in Context. In L. Sears \& S. Raffel (Eds.), The 5th Asia-Pacific Triennial of Contemporary Art (pp.32-42). Brisbane: Queensland Art Gallery Publishing.

Kaeppler, A. L. (1972). Method and theory in analyzing dance structure with an analysis of Tongan dance. Ethnomusicology, 16(2 ), 173-217.

Kempf, W. (2003). "Songs cannot die": Ritual composing and the politics of emplacement among the resettled Banabans on Rabi Island in Fiji. The Journal of the Polynesian Society, 112(1), 33-64.

Kempf, W., \& Hermann, E. (2005). Reconfigurations of place and ethnicity: Positionings, performances and politics of relocated Banabans in Fiji. Oceania, 75, 368-386.

Lawson, M. E. (1989). Tradition, change and meaning in Kiribati performance: An ethnography of music and dance in a Micronesian society (Doctoral dissertation). Brown University, Providence, RI.

Lessig, L. (2008). Remix: Making art and commerce thrive in the hybrid economy. London, England: Penguin Press.

The lifeblood of New Zealand farming: The fascinating story of the Nauru and Ocean Islands phosphate deposits. (1956). New Zealand Fertiliser Journal, July, 11-13.

Moulin, J. (1979). The dance of Tahiti. Pape'ete, French Polynesia: Les Editions du Pacifique/Hachette.

Moyle, R. (1991). Polynesian music and dance. Auckland, New Zealand: Centre for Pacific Studies, University of Auckland.

Nepia, M. (2013). Te kore: Exploring the Māori concept of void (Unpublished Doctoal thesis). Auckland University of Technology, Auckland, New Zealand.

Peabody Museum of Archaeology \& Ethnology. (2013). REMIX: Indigenous identities in the 21st century; Exhibition of four visual artists. Retrieved from https: / / peabody.harvard.edu/node/165

Pennington, R. (2013). Five questions with Katerina Teaiwa. Framing the global. Retrieved from http: / / framing.indiana.edu/2013/12/02/five-questions-katerina-teaiwa/

Reilly, E. (2010). Remix culture: Digital music and video remix opportunities for creative production. In J. Parker (Ed.), Teaching tech-savvy kids: Bringing digital media into the classroom, Grades 5-12 (pp. 143-166). Thousand Oaks, CA: Corwin Press.

Rowe, N. (2010). Raising dust: A cultural history of dance in Palestine. London, England: I.B. Tauris.

Shennan, J. (1981). Approaches to the study of dance in Oceania. Journal of the Polynesian Society, 90(2), 193-208.

Shennan, J. (2012). Obituary: Beth Dean Carroll. Danz Quarterly: New Zealand Dance, 28, 18. 
Shennan, J., \& Corrie Tekenimatang, M. (Eds.). (2005). One and a half Pacific Islands: Stories the Banaban people tell of themselves. Wellington, New Zealand: Victoria University Press.

Simet, N. F., \& Niles, D. (Eds.). (2012). A focus on dance in PNG. Boroko, Papua New Guinea: Institute of Papua New Guinea Studies.

Spriggs, M. (2009). Oceanic connections in deep time. PacifiCurrents: eJournal of the Australian Association for the Advancement of Pacific Studies, 1(1), 7-27.

Stillman, A. (1998). Sacred hula: The historical hula ala'apapa. Honolulu, HI: Bishop Museum Press.

Teaiwa, K. (2000). Banaban Island: Paying the price for other people's development. In N. Maclellan \& D. Vinding (Eds.), IWGIA: Journal of the International Work Group on Indigenous Affairs, 1(2000), 38-45.

Teaiwa, K. (2002). Visualising te kainga, dancing te kainga: History and culture between Rabi, Banaba and beyond (Unpublished doctoral thesis). Australian National University, Canberra, ACT, Australia.

Teaiwa, K. (2004). Multi-sited methodologies: Homework between Fiji, Australia and Kiribati. In J. Mulcock \& L. Hume (Eds.), Anthropologists in the field (pp. 216-233). New York, NY: Columbia University Press.

Teaiwa, K. (2005). Our sea of phosphate: The diaspora of Ocean Island. In G. Harvey \& C. D. Thompson Jr. (Eds.), Indigenous diasporas and dislocations: Unsettling Western fixations (pp.246-297). London, England: Ashgate Press.

Teaiwa, K. (2008). Salt water feet: The flow of dance in Oceania. In S. Shaw \& A. Francis (Eds.), Deep blue: Critical reflections on nature, religion and water (pp.107-125). London, England: Equinox.

Teaiwa, K. \& Mercer, C. (2011). Pacific Cultural Mapping, Planning and Policy Toolkit. New Caledonia: The European Union and the Human Development Programme, Secretariat of the Pacific Community.

Teaiwa, K. (2012). Choreographing difference: The (body) politics of Banaban dance. The Contemporary Pacific, 24(1), 65-94.

Teaiwa, K., Henderson A., \& Mallon, S. (Eds.). (2012). Dance, gender and the moving body in Oceania [Special issue]. Intersections: Gender and Sexuality in the Asia Pacific, 27. Retrieved from http://intersections.anu.edu.au/issue27_contents.htm

Teaiwa, T. (2010). For or before an Asia-Pacific studies agenda. In T. Wesley-Smith \& J. Goss (Eds.), Remaking area studies: Teaching and learning across Asia and the Pacific (pp.110-124). Honolulu, HI: University of Hawai' ${ }^{i}$ Press.

University of Hawai ${ }^{`} i$, Center for Pacific Islands Studies. (2005). Culture moves: Dance in Oceania from hiva to hip hop. Retrieved from http://www.hawaii.edu/cpis/dance/ 